\title{
PDPK1 wt Allele
}

National Cancer Institute

\section{Source}

National Cancer Institute. PDPK1 wt Allele. NCI Thesaurus. Code C51254.

Human PDPK1 wild-type allele is located in the vicinity of $16 \mathrm{p} 13.3$ and is approximately 63 $\mathrm{kb}$ in length. This allele, which encodes 3-phosphoinositide-dependent protein kinase 1 protein, plays a role in the activation of a number of signaling pathways involved in cell proliferation and survival. 